\title{
Importance of the list of essential medicines in medical prescription
}

Luis Jasso, Alberto Lifshitz, Oscar Arrieta, Rubén Burgos, Carlos Campillo, Miguel Á. Celis, Manuel de la Llata, Judith Domínguez, José Halabe, Sergio Islas, Mucio Moreno, Ricardo Plancarte, Alejandro Reyes-Sánchez, Guillermo Ruiz-Argüelles, Antonio Soda, Julio Sotelo* and Emma Verástegui Academia Nacional de Medicina, Comité de Ética y Transparencia en la Relación Médico-Industria (CETREMI), Mexico City, Mexico

\begin{abstract}
The implementation of an essential medicines list in health institutions allows acquiring and administering a long list of drugs that offers treatment alternatives to physicians, as well as a collegiate academic description of indications, doses, side effects, interactions and cost-benefit analyses, thus facilitating medical prescription and administration of health products. The Committee of Ethics and Transparency in the Physician-Industry Relationship issues several recommendations for optimizing the benefits generated by essential medicines lists.
\end{abstract}

KEY WORDS: Essential medicines list. Medication cost. Prescription. Cost-benefit. New drugs.

\section{Importancia del cuadro básico de medicamentos en la prescripción médica}

\section{Resumen}

La implementación en instituciones de salud de un cuadro básico permite adquirir y administrar una larga lista de medicamentos que presenta a los médicos las alternativas de tratamiento, así como la descripción académica colegiada de indicaciones, dosis, efectos secundarios, interacciones y análisis de costo-beneficio, con lo que se facilita la prescripción médica y la administración de insumos para la salud. El Comité de Ética y Transparencia en la Relación Médico-Industria emite diversas recomendaciones para la optimización de los beneficios generados por los cuadros básico de medicamentos.

PALABRAS CLAVE: Cuadro básico. Costo de medicamentos. Prescripción. Costo-beneficio. Nuevos fármacos.

Essential medicines lists (there are also lists for equipment and other supplies) have been valuable aids for administration in health institutions. Currently, for symbolic reasons that consider only their disadvantages, there is a tendency to rename them with an equivalent such as catalog, index or compendium, although their main purpose is administrative, since their greatest usefulness lies in guiding institutional administrators to know what to buy and focusing on studies on quality impact or cost of care. The truth is that essential medicines lists undoubtedly influence doctors' prescriptions. Herein, medical issues will be discussed, trying to define a position of the National Academy of Medicine Committee of Ethics and Transparency in the Physician-Industry Relationship (CETREMI - Comité de Ética y Transparencia en la Relación Médico-Industria). ${ }^{1}$

The main criticism to essential medicines lists is that they restrict prescription freedom, on the grounds that
Correspondence:

*Julio Sotelo

E-mail: jsotelo@unam.mx
Gac Med Mex. 2020;156:598-599

Contents available at PubMed

www.gacetamedicademexico.com

0016-3813/@ 2020 Academia Nacional de Medicina de México, A.C.. Published by Permanyer. This is an open access article under the CC BY-NC-ND license (http://creativecommons.org/licenses/by-nc-nd/4.0/). 
it is a restrictive rule manipulated by pharmaceutical interests, and that medicines not included in the referred catalog cannot be used in health institutions.

Similarly, essential medicines list advantages in terms of quality of service should be defined.

Inclusion of drugs in essential medicines lists is based on a consensus among health institutions, which largely prevents the acquisition of useless drugs or those with unproven usefulness, as many exist on the market. Doctors can see in the essential medicines list a guide generated by experts that includes useful drugs that have good cost-benefit ratios; in addition, it contains information on indications, routes of administration, dosage, clinical algorithms, adverse effects and interactions. It is, in a certain way, a prescribing guideline that is not biased by commercial interests. Clearly, a good essential medicines list must have the flexibility to incorporate innovations in a timely manner and allow exceptions based on solid, scientifically supported information. Its main utility is to promote a good supply, since in no system is it possible to have the vast totality of medicines offered by the market (the regulation of which is imperfect).

Institutions guide their purchases and supplies through a catalog of the most commonly used drugs, as long as they have evidence on efficacy and safety. In Mexico, the General Public Health Council generates an essential medicines list for the government health sector, which now will be called National Compendium of Health Supplies. With this, the grouping and classification of drugs authorized by the General Public Health Council and their acquisition by health institutions is managed to be as uniform as possible, both in quality and cost. Uniformity in the application of each one is also achieved by providing information on their respective side effects, routes of administration, dosage and possible adverse effects. At the same time, the catalog allows the calculation of the amount of medicines and monetary resources each health institution will require.

Essential medicines lists are not intended to limit physicians decisions, but rather to promote that institutions have the necessary supplies for an optimal practice of the profession, as well as to attempt rationality of prescription without the influence of commercial interests. A relevant aspect for essential medicines list to maintain its maximal usefulness is frequent updating, by collegiate experts, with incorporation or withdrawal of drugs and indications according to the results of relevant and recent scientific research and convenience based on cost-benefit analyses.

\section{Conflicts of interest}

The authors declare that there are no conflicts interest.

\section{Funding}

None

\section{Ethical disclosures}

Protection of human and animal subjects. The authors declare that no experiments were performed on humans or animals for this research.

Confidentiality of data. The authors declare that no patient data appear in this article.

Right to privacy and informed consent. The authors declare that no patient data appear in this article.

\section{References}

1. Academia Nacional de Medicina. Comité de ética y transparencia de los médicos con la industria farmacéutica (CETREMI). Gac Med Mex. 2015;151:293. 